\title{
IDENTIFICATION AND INHIBITION OF BIOACTIVE COMPOUNDS FROM NUTMEG ( Myristica fragrans Houtt ) AND THE APPLICATION AS ANTIBACTERIAL AGENT
}

\author{
Dede Zainal Arief \\ Fitri Widiyantari \\ Hervelly \\ Department of Food Technology, Faculty of Engineering, Pasundan University, Bandung, 40153, Indonesia \\ E-mail : ariefalbuchari@gmail.com
}

\begin{abstract}
The purpose of this research is to determine the most effective of nutmeg meat products to inhibit the specific spoilage bacteria based on inhibitory zone and determine the power of antibacterial compounds in nutmeg meat to inhibit and kill specific spoilage bacteria based on the number of growth of spoilage bacteria. This research consists of two stages: The purpose of first stage is to determine the most effective of nutmeg meat products as an antimicrobial agent to inhibit gram-positive and gram-negative bacteria with inhibition test response. The second stage of the main research continued from preliminary research that consists of three steps. The purpose of first step is to determine the best long immersion antimicrobial substances against bacteria growth in fresh meat for 0 minute, 5 minutes, 10 minutes, 15 minutes and 20 minutes. The purpose of second step is to determine the correlation between the concentration of antimicrobial agent $5 \%, 10 \%, 15 \%, 20 \%$ and $25 \%$ of the microbial growth number in fresh meat stored within 5 days. The analysis was performed using total plate count method. The purpose of third step is to determine the level of concentration that is acceptable to consumers. Based on the results of research was obtained that the nutmeg meat essential oil can inhibit the growth of gram positive and negative bacteria. If concentration of antimicrobial substances are higher, so that the power of inhibit to against spoilage bacteria in fresh meat is higher. The selected concentration by organoleptic test that acceptable by consumers is $10 \%$.
\end{abstract}

Keywords: nutmeg, antimicrobial substances, essential oils

\section{Preliminary}

Food safety issues is still a major problem in food products. According to the FAO by Stefani (2013), explain that food security is the guarantee that food will not causing hazard to the consumer when prepared or eaten with a purpose to getting its usefulness. The definition of food security according to Law Decree No. 7 of 1996 on Food and Government Regulation No. 28 of 2004 on Safety, Quality and Nutrition is a condition and effort which needed to prevent food from possible biological contamination, chemical and a strange material that may distracts, harm and endanger of human health (State Gazette of the Republic of Indonesia, 1996).

Preservative commonly used to preserve food that has a perishable characteristic. In fact the producers often use it on relative sustainable food with the purpose to extend the shelf life or improve texture. Preservatives used in food materials must be appropriate, both of the type and dose. A preservative may be effective for preserving specific foods, but it is not effective to preserve other food because food has a different characteristic (Winarno and Rahayu, 1994).
Results of several researches had shown that herbs and original spices from Indonesia apparently contains many antimicrobial active substances that have potential to be used as a natural preservative one of them which is nutmeg plant. Nutmeg plant (Myristica fragrans Houtt) is an original plant from Indonesia, which comes from Banda island (Rismunandar 1990).

The efforts to provide value-added meat nutmeg that is necesarry to be performed research on biological activity (antibacterial activity) in fresh meat and the identification of antibacterial components contained in meat nutmeg.

\section{Researdh Method}

Materials that used are nutmeg meat from Wanayasa, Purwakarta. Supporting materials used are distilled water, tween 80 , fresh meat, alcohol 70 $\%$, PCA (Plate Count Agar), sterile water, fresh pure bacterial culture of Staphylococcus aureus and Salmonella sp. The instruments used are the scales, Petri dish, tunnel drier, tray, paper millimeter, autoclaves, incubators, tweezers, needle ose, microliter pipette, pipette tip, the paper discs and GC - MS . 
How It Works

Preparation and analysis of nutmeg juice. Whole nutmeg had done trimming, then washed with clean water, and separate the seeds and the mace. The meat nutmeg crushed with circuitry blender. Puree of meat nutmeg filtered. After that the water content, yield, density and $\mathrm{pH}$ nutmeg fruit juice was analyzed.

Production the powder and essential oil of meat nutmeg. Whole nutmeg had done trimming and washing. After that separate the seeds and mace. Chopped the flesh of the fruit with a thickness of $\pm 1 \mathrm{~cm}$. Dried the flesh of the fruit with tunnel drier with a temperature of $60^{\circ} \mathrm{C}$ for \pm 8 hours. Simplicia divided into 2 parts. The first part was destroyed and sifted until produced meat nutmeg powder. The other part is distilled at a temperature of $95^{\circ} \mathrm{C}$ for 5 hours. Result of product was analyzed are water content, yield, density and $\mathrm{pH}$. Essential oil compounds contained components were analyzed using GC-MS.

Testing inhibition. According to Zang et al (2009) explain that concentrations that used to inhibit the growth of spoilage bacteria was $5 \%$. Sample diluted until a concentration of $5 \%$. Instruments and media which will be used must be done sterilized by autoclave. Paper discs soaked with a liquid sample for 5 minutes to sink into the paper discs completely. The media which already poured into petri dishes and inoculated gram positive and negative bacteria are pinned up with paper discs on media surface. One petri dish of one diffusion. Duplo treatment. Petri dishes were incubated at $37^{\circ} \mathrm{C}$ for 24 hours. After 24 hours the petri dishes observed, they were formed a clear zone, then shall be done measurements on three different sides and averaged.

Testing inhibition by long immersion. The sample used is fresh beef. Fresh meat weighed $1 \mathrm{~g}$, then soaked in antimicrobial agent selected by the time variation of $0,5,10,15$, and 20 minutes. After that the meat is drained and wrapped in sterile plastic. Fresh meat stored at room temperature for $0-24$ hours. The analysis is used by TPC method at the time of analysis at the beginning and end of storage. Duplo treatment.

Testing inhibition by concentration. The sample is fresh beef which weighed as much as $1 \mathrm{~g}$, then soaked in antimicrobial substance selected with the variation of concentrations of $0 \%, 5 \%$, $10 \%, 15 \%, 20 \%$, and $25 \%$. After the meat is drained and wrapped in sterile plastic. Meat stored at room temperature for 0-120 hours. The analysis is used by TPC method at the time of analysis at the beginning and per 24 hours during storage. Duplo treatment.

Organoleptic test. Fresh beef had soaked with selected products with variations in the concentration of $5 \%, 10 \%, 15 \%, 20 \%$, and $25 \%$. Treatment of fresh meat and processed meat with natural preservative (boiled) without washing and with washing. Organoleptic test was hedonic test with the aroma and texture attributes in fresh meat, and aroma, texture and flavor in processed meats (boiled).

\section{Rsult and Discussion}

Based on observational data obtained that the moisture content of nutmeg juice is $98.5 \%$, meat nutmeg powder is $14.2 \%$ by gravimetric method and essential oil of meat nutmeg is $0 \%$. The yield of meat nutmeg juice is $73.8 \%$ (wet weight) and meat nutmeg powder is $5.5 \%$ (dry weight). The density of nutmeg juice is $1.016 \mathrm{~g} / \mathrm{ml}$, essential oil of meat nutmeg is $0.915 \mathrm{~g} / \mathrm{ml}$ and meat nutmeg powder is $0.43 \mathrm{~g} / \mathrm{ml}$. $\mathrm{pH}$ of nutmeg juice is 2.96 , 2.90 of nutmeg meat powder and essential oil of meat nutmeg is 3.17 .

Water content is one important of chemical aspect in agriculture. Water content is the percentage of water content of a material, which can be expressed based on the weight of wet or dry weight (Syarief, et al., 1993). The product that has a low water content would be more difficult to microorganisms growth.

Yield is the percentage of products obtained from first weight with end weight (Vogel, 1988). The factors that influence the yield is from the climate and place of raw materials growth, raw material age, season, preparation or handling of raw materials, process, and raw material quality (Yuhono et al, 2006).

Density is very related with the concentration of an antimicrobial agent. The higher concentration of an antimicrobial that will be the smaller density. Density from a subtance also can formulating with the other subtances easily, because by knowing the density of it, so that can determine whether a substance can be mixed or not with the other substances (Martin, 1990).

$\mathrm{pH}$ from each nutmeg meat products has a low value and has a high acidic of $\mathrm{pH}$ that can be potentially as an antimicrobial agent to inhibit the growth of pathogenic bacteria (Fardiaz, 1992).

The purpose of antibacterial inhibition is to determine the type of nutmeg meat products to against specific gram positive and negative bacteria. The media that used in this method is PCA (Plate Count Agar). Antibacterial ability of each type in nutmeg meat products with a concentration of $5 \%$ is shown by clear zone diameter around the paper disc. Measurement clear zone of each type of nutmeg meat products can be seen in the table below. 
Table 1. The average diameter of inhibition zone Staphylococcus aureus ATCC 25923 and Salmonella typhi NCTC 786 Bcc 712 bacteria about various kind of nutmeg meat products.

\begin{tabular}{|l|l|l|}
\hline \multirow{2}{*}{ Varian of product } & \multicolumn{2}{|c|}{$\begin{array}{c}\text { Inhibition diameter } \\
\left(\mathrm{cm}^{2}\right)\end{array}$} \\
\cline { 2 - 3 } S.aureus & S.typhi \\
\hline $\begin{array}{l}\text { Positive control } \\
\text { (chloramphenicol) }\end{array}$ & 13,23 & 17,83 \\
\hline $\begin{array}{l}\text { Negative control } \\
\text { (aquadest+emulsifier) }\end{array}$ & - & - \\
\hline Meat nutmeg powder 5\% & 2,26 & - \\
\hline nutmeg juice 5\% oil of meat & - & - \\
\hline $\begin{array}{l}\text { essential oil } \\
\text { nutmeg 5\% form unit }\end{array}$ & $403 \times 10^{3}$ & $138 \times 10^{3}$ \\
\hline $\begin{array}{l}\text { Colony } \\
\text { (cfu/ml) }\end{array}$ & 1,99 \\
\hline
\end{tabular}

Clear zone (zone of inhibition) around the paper disc indicates a positive test antibacterial, that clear diameter area is measured and compared to the standard antibiotic compound chloramphenicol as a positive controls and solvents used for sample as a negative control. Based on observations obtained in Table 1, it can be seen that the growth of gram-positive bacteria test that given with nutmeg meat powder, nutmeg juice, and essential oils of meat nutmeg after incubated for $1 \times 24$ hours known that meat nutmeg powder and essential oil of meat nutmeg have a clear zone diameter, the inhibition zone area for meat nutmeg powder is $2.26 \mathrm{~cm}^{2}$ and essential oil of meat nutmeg is $3.19 \mathrm{~cm}^{2}$. The growth of gram-negative bacteria that given test with meat nutmeg powder, nutmeg juices, and essential oils of nutmeg meat after incubated for $1 \times 24$ hours noted that only essential oil of meat nutmeg which has a diameter of inhibitory zone is $1.99 \mathrm{~cm}^{2}$.

Antibacterial activity of essential oils from meat nutmeg give positive results against gram positive and negative bacteria were tested that is the essential oil formed a clear zone around the paper disc. Diffusion ability of antibacterial substances into the medium in order to determine the inhibitory against S. aureus and S.typhi. According to Davidson and Parish (1989) the size of clear zone depends on the speed of diffusion of antibacterial compounds on agar media, which is if diffusion of antibacterial compounds into the agar medium is faster, so that the zone of inhibition is formed more extensive than the slower antibacterial compounds.

Based on the description above, it can be concluded that essential oil has the largest inhibitory zone between the three types of meat products nutmeg, it is because of the components in essential oil has antimicrobial ability that are terpenoids and phenolic compounds (Corner, 1993 and Harborne, 1996).

Phase II of this research conducted by calculation Simple Linear Regression method. The parameters that measured were the number of microbes colonies growth and measured per 24 hours with a free variable that is long immersion and concentration of essential oils that applied to the meat.

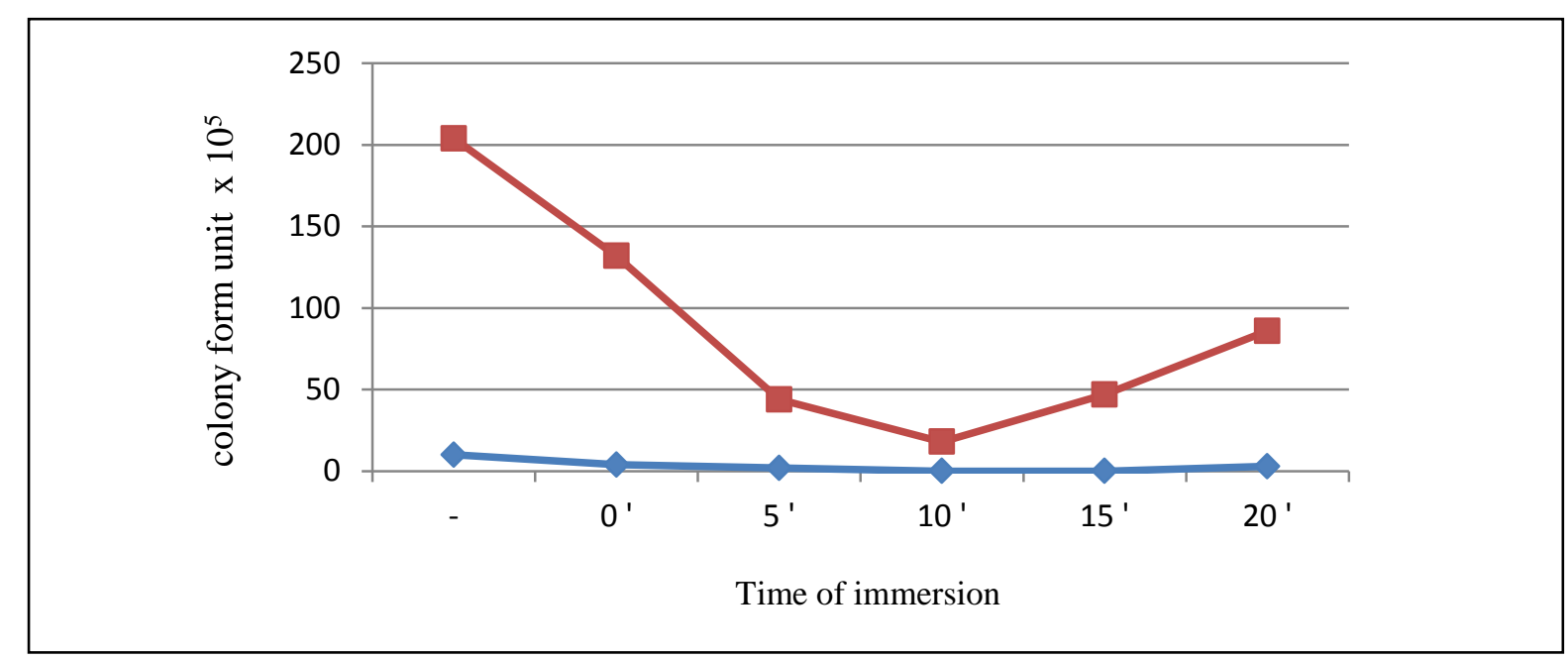

Figure 1. Graph of Microorganisms Inhibition After Immersion Process with Antimicrobial Compounds.

Description: $\triangleleft$ Total of microbial colonies after 0 hours storage.

Total of microbial colonies after 24 hours storage.

If immersion time is longer,so that total growth of microorganisms is higher. Total growth of microorganisms that increased because the microorganisms to be resistant with that antimicrobial compounds. Resistance is the ability of bacteria not get killed or stunted by an antibacterial. Resistance can occur naturally or develop (acquired) (Mutschler, 1991). Immersion 
time with a time of 10 minutes is the optimum time for total growth of microorganisms does not increase too high after storage during 24 hours so that it can be concluded that for 10 minutes is the best immersion time to reduce the number of microbes that contained in fresh beef.

Inhibition growth of microorganisms can occur due to the addition of a preservative treatment (essential oil of meat nutmeg) into the meat. Reduction the number of cells of microorganisms in meat occurs when soaking the meat for 10 minutes, during the microorganisms had died because of damage cell walls, cell permeability changes, protein and nucleic acid molecules changes, inhibition of the enzyme and inhibition of protein and synthesis of nucleic acids
(Pelczar, 2005). Unsupported environment may also influence the rate of growth of microorganisms such as essential oil which has low $\mathrm{pH}$, so that the microorganisms can not grow well (Fardiaz, 1992).

Preservatives or chemicals are compounds that can inhibit or blocked all kinds of changes in food materials caused by the activity of microorganisms. Preservatives have a variety that are preservatives which will inhibit the growth of microbes, but the microbes themselves stayed alive and preservatives that are killed the microorganisms (Hudaya et al, 1981). Total microorganisms growth from the first day until the fourth day with addition variative concentrations of essential oil can be seen in Figure 1.

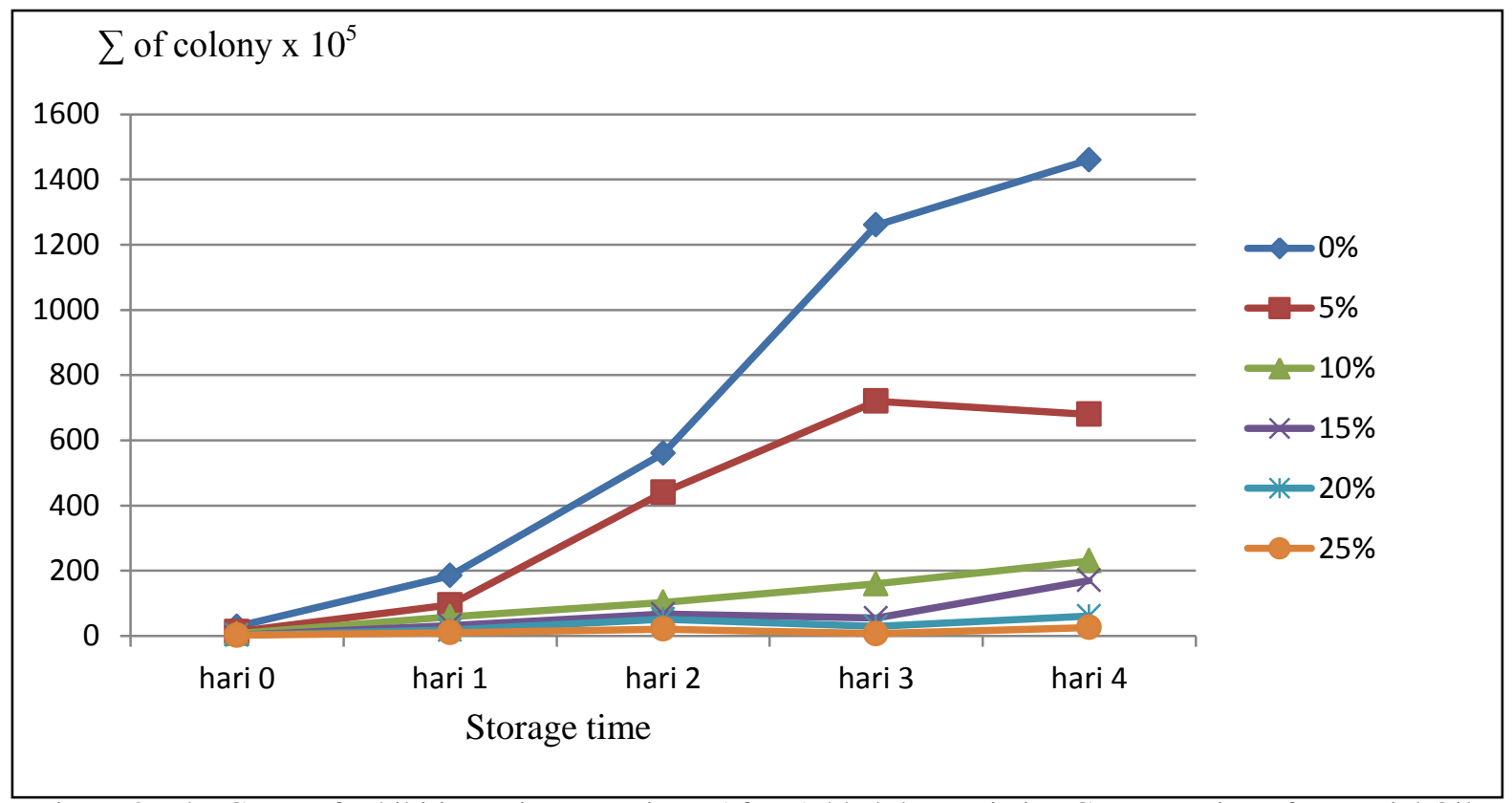

Figure 2. The Curve of Inhibition Microorganisms After Added the Variative Concentration of Essential Oil

Based on the growth curve of microorganisms above can be concluded that time of 0-4 days total microorganisms contained in fresh beef decreased significantly after soaking with different concentration with antimicrobial agent because the essential oil of meat nutmeg has antimicrobial substances that are able to reduce the amount of microbial growth. If concentration of essential oil is higher, so that the growth of microbes contained in meat become low.

According to Madigan et al (1997) antibacterial compound diffuses into the medium can inhibit the formation of thin cell walls and can lysis. Inhibition also occurs because of a process of protein synthesis. Protein synthesis inhibition occurs where process of transcription and translation of genetic material, so that the amino acids that produced was wrong position in the peptide chain and produced unfunction proteins. Enzymes are become a potential target of antibacterial compounds. This inhibition generally irreversible that occur, so that the enzyme becomes inactive. With inhibit or block of enzyme activity, the mechanism of enzyme can be disrupted, so that can be affected the growth of bacterial cells (Pelczar and Chan, 2005).

The shelf life of fresh beef prior to pickling only maximum of 2 days if the handling of the first well (Winarno in Hudaya et al, 1981). Beef after given a natural preservatives such as essential oil of meat nutmeg can hold until 3 days. If concentration of essential oil is higher, so that the microbial growth become low because of several factors that are $\mathrm{pH}$ and antimicrobial compounds in essential oil. Preservation mechanism that occurs is based on the permeability of microorganisms cell membranes against acid molecules that are not biodegradable. Contents of microbial cells that have a neutral $\mathrm{pH}$ when the cytoplasm has an acidic $\mathrm{pH}$, there will be a disruption to the organs of the 
cell so that the metabolism can be inhibited (Hudaya et al, 1981).

Essential oils (essential) in foods of original plant is an antimicrobial agent. This antimicrobial agent has a specific job so that food materials that contain added substances can be damaged when attacked by microorganisms that are resistant to available antimicrobial factors. Antimicrobial agent can be removed by solving (decomposition) of hydrogen peroxide formed by the catalase-negative organisms, oxidation of acetic acid by the type acetobacter and reduction of fat peroxide by various bacteria may provide an opportunity for microorganisms that were blocked before now able to grow, so that the several kinds of microorganisms allow previously stunted take part in the process of destruction (Buckle, 1985).

One important characteristic of bacteria in relation to food microbiology is the ability of some bacteria to produce internal structure that is endospores. Endospores are generally formed singly in a cell in order to cope with unfavorable circumstances. Ripe spores released by the cell into the surrounding nature. These spores are resistant with extreme physical circumstances such as temperature, drought and chemicals disinfectants and can survive in a state of sleep for a few years and when the growing conditions allow, the spores grow into normal vegetative cells (Buckle, 1985).

Results of GC-MS analysis can be expressed by the retention volume $\mathrm{Rv}$, that is the volume of carrier gas required for a component elute from the column, or can be expressed by the retention time (Rt), that is the time required for the component elute from the column (Harborne, 1987).

Based on data chromatogram obtained from the analysis that the components contained in the essential oil of meat nutmeg has antimicrobial activity include $1 \mathrm{R}-\alpha$-pinene with a retention time of 14.095 minutes with an area of $16.65 \%$ and a high area of $18,41 \%$ is a compound that has the highest and widest peak, $\beta$-pinene with a retention time of 17.846 minutes with an area of $10.96 \%$ and $10.04 \%$ higher area, alpha terpinene with a retention time of 20.890 minutes with an area of $5.45 \%$ and area high of $6.34 \%$, d-Limonene with a retention time of 21.774 minutes with an area of $8.33 \%$ and $8.13 \%$ higher area, alpha-terpinolene with a retention time of 26.202 minutes with an area of $4.59 \%$ and a high area $4.40 \%$, 4-terpineol with a retention time of 32.569 minutes with an area of $6.93 \%$ and high area is $6.96 \%, 1$-allyl-3,4methylene-dioksi-5-methoxy-benzene with retention time 55.262 minutes with a total area of $16.70 \%$ and a high area is $11.72 \%$. The dominant component contained in the nutmeg meat essential oil has antimicrobial activity, so it can be used as a substitute for synthetic preservatives that are circulating like borax and formaldehyde (Cahyadi, 2009).
Results from the overall organoleptic attributes can be concluded that the concentration still be accepted by consumers is the concentration of $10 \%$, if the concentration is higher, so that the level of non-conformity with the meat without the addition of an antimicrobial agent will be increased.

The essential oil of meat nutmeg is a selected product in the main research with a water content is $0 \%$, $\rho$ of $0.915 \mathrm{~g} / \mathrm{ml}$, and 3.17 of $\mathrm{pH}$ with a diameter of inhibition zone on gram-positive bacteria is $3.19 \mathrm{~cm}^{2}$ and gram-negative bacteria is $1,99 \mathrm{~cm}^{2}$. The concentration of antimicrobial compounds nutmeg meat has a negative correlation with the growth of spoilage bacteria in fresh meat. The concentration of antimicrobial compound that can kill microbes minimal spoilage is $5 \%$. The highest component antimicrobial compounds in volatile oil is $1 \mathrm{R}-\alpha$-pinene with an area of $16.65 \%$ and $18.41 \%$ higher area. The level of concentration of antimicriboal compound that can accepted to customer is $10 \%$.

\section{BIBLIOGRAPHY}

1. Agency for Food and Drug Control of Indonesia. Illegal Additive 2004. Borax, formaldehyde and Rhodamine B. Food Watch the Integrated Food Security System.

2. Buckle, K.A., R.A. Edwards, G.H. Fleet and M. Wooton. 1985. Food Science. UI-Press publisher Press.Jakarta.

3. Cahyadi, W. 2009. Analysis and Health Aspects of Food Additives. PT Bumi Aksara. Jakarta.

4. Conner, D. E. 1993. Naturally occuring Compounds. In: A.L. Branen and P. M Davidson (eds.). Antimicrobial in Food. Marcel Dekker. New York.

5. Fardiaz, S. 1992. Processing Advanced Microbiology. Director General of Higher Education. Department of Education. PAU IPB. Bogor.

6. Harborne, JB 1987. Phytochemical Methods: Guidance How Modern Analyze Plants. Translated by: K. Padmawinata and I. Soediro. Publisher ITB. Bandung.

7. Biological, EK 2009. Food Preservatives, a Lesson For halalan Toyyiban Determination. Faculty of Science and Technology. UIN. Malang.

8. Hudaya, S and Setiasih, D. 1981. Preservation Basics I. Ministry of Education and Culture.

9. Gazette of the Republic of Indonesia. 1996. About the Food Act. (Http://www.pom.go.id/pom/garam/LEMBAR AN_NEGARA.pdf, accessed on 6/01/2014.)

10. Madigan, Michael T., Martinko, JM, Parker, P. 2003. Biology of Microorganism. $10^{\text {th }} \mathrm{ed}$. 
Southern Illinois University Carbondale. New York.

11. Martin A., Swarbrik J., and Cammarata A. 1990. Physical Pharmacy. University of Indonesia - Press. Jakarta.

12. Mutschler, E.1991. Drug dynamics. Textbook of Pharmacology and Toxicology. ITB. Bandung.

13. Nurdjannah, Nanan. 2007. Processing Technology of Nutmeg. Center for Post Harvest Research and Development of Agriculture. Accessed on 12/17/2013.

14. Parish, M.E. and P.M. Davidson. 1993. Method for Evaluation. In: Antimicrobial In Food. P.M. Davidson and A.L. Branen (Eds.). 2nd Ed. Marcel Dekker, Inc. New York: 597612.

15. Pelczar, MJ, and Chan, ECS 2005. Fundamentals of Microbiology II. Translation by Ratna Sari Hadioetomo. University of Indonesia. Jakarta.

16. Rismunandar, 1990. The cultivation and nutmeg trading system. PT. Penebar Organization. Second printing. Jakarta.

17. Stefani, DL 2013. Public Health Nutrition "Food Safety". (Delfistefani.wordpress.com/2013/12/15/makal ah endurance-food /. Accessed on 02.04.2014.)

18. Syarief, R and Hariyadi, H. 1993. Food Storage Technology. Publisher Arcan. Jakarta.

19. Vogel, A.L. 1988. Elementary Practical Organic Chemistry. Longmans. Greenan Co. New York.

20. FG Winarno, and Rahayu TS. 1994. Additives and Contaminants in Food. Pustaka Sinar Harapan. Jakarta.

21. Yuwono, S and Susanto, T. 1998. Physical Testing of Food. FTP UB. Hapless

22. Zang, H., B. Kong., Y. L. Xiong, and X. Sun. 2009. Antimicrobial Activities of Spice Extracts Against Pathogenic Bacteria and spoilage in Modified Athmosphere Package Fresh Pork and Ham Slices Packaged Vacuum Stored at $4^{0}$ C. Meat Sci (81): 686-692 